European journal of American studies

Special Issue: May 68

\title{
Up Against the Wall: Primal Therapy and 'the Sixties'
}

\section{Paul Williams et Brian Edgar}

\section{(2) OpenEdition \\ Journals}

Édition électronique

URL : https://journals.openedition.org/ejas/3022

DOI : 10.4000/ejas.3022

ISSN : 1991-9336

Éditeur

European Association for American Studies

Référence électronique

Paul Williams et Brian Edgar, « Up Against the Wall: Primal Therapy and 'the Sixties' », European journal of American studies [En ligne], 3-2 | 2008, document 3, mis en ligne le 08 septembre 2008, consulté le 08 juillet 2021. URL : http://journals.openedition.org/ejas/3022 ; DOI : https://doi.org/10.4000/ejas. 3022

Ce document a été généré automatiquement le 8 juillet 2021.

Creative Commons License 


\title{
Up Against the Wall: Primal Therapy and 'the Sixties'
}

\author{
Paul Williams et Brian Edgar
}

\section{Introduction}

1 Primal Therapy, a form of psychological treatment based on expelling neurosis through emotional expression, was developed by the Californian psychotherapist Arthur Janov. His work became well known across the Anglophone world with the 1970 publication of The Primal Scream (subtitled Primal Therapy: The Cure for Neurosis). It is claimed this book sold more than one million copies internationally, which - if true - makes it one of the best-selling psychology books ever. In 1968 Janov had established the Primal Institute in Los Angeles; Institutes in New York and eventually Paris followed, both of which are now closed. He has run the Primal Center in Venice/Santa Monica since 1989, while his ex-wife Vivian is currently Executive Director of the nearby Primal Institute. His first book was followed by more than a dozen titles, none as popular or commercially successful as the founding text. Primal Therapy - or at least the ideas behind it resonated with American and British cultural producers in the 1970s, but since then it seems largely forgotten. It is time to re-evaluate the historical conditions for the creation of the therapy, and to consider its cultural legacy. ${ }^{\mathrm{i}}$

Situating Primal Therapy in the context of the 1960s counterculture demonstrates that in some of its aspects the therapy was an amalgam of the ideologies of the 1960s youth movement translated into therapeutic terms. Primal Therapy also incorporated a critique of the counterculture that inspired it, one dedicated to making it more able to fulfil its revolutionary goals. After the success of The Primal Scream, Janov addressed directly some basic questions in countercultural politics: should freedom from the 'old' world take the form of mass political emancipation or the liberation of the individual self? Are these two options predicated on each other or mutually exclusive? We shall argue that the early development of the therapy can be better understood by attending to this context of countercultural political radicalism. Janov's relationship to such radicalism was complex: identifying several countercultural practices as evidence of unresolved 'Pain', he offered a sceptical annotation of new-leftist politics, suggesting 
that any radical social upheaval must also address personal trauma. To illustrate the influence of such ideas in the early 1970s, we discuss the album John Lennon / Plastic Ono Band (1970), written and performed by John Lennon and Yoko Ono (both of whom undertook Primal Therapy) and the novel Dead Babies (1975) by British writer Martin Amis (who, as far as we know, had no personal connection with Janov). Finally, this article interrogates the significance of Primal Therapy's ambiguous endurance in psychotherapeutic and popular culture.

2. Primal TherapyThe Discovery of Primal Therapy

3 The Primal Scream opens with a classic piece of 1960s writing:

Some years ago, I heard something that was to change the course of my professional life and the lives of my patients. What I heard may change the nature of psychotherapy as it is now known -- an eerie scream welling up from the depths of a young man lying on the floor during a therapy session. I can liken it only to what one might hear from a person about to be murdered. This book is about that scream and what it means in terms of unlocking the secrets of neurosis. (Janov 1970, 9)

4 Janov elicited this response by getting his patient ('Danny') to call for his parents. He discovered that this or similar techniques would often produce the same result: an emotional response concluding in an uncanny scream. He came to regard that scream as the product of universal neurotic pain (Janov 1970,11). This was the key to Primal Therapy's therapeutic journey: patients return to painful moments in their early lives and experience them fully for the first time, sometimes to the accompaniment of thrashing and flailing, pillow punching or yelling and pleading directed (typically) at parents. The 'primal scream' was one way patients voiced their Pain. By reliving this Pain and ending the repression built up around it, Janov claimed, patients who completed Primal Therapy could live free of neurosis.

The Spread of Neurosis

5 This therapeutic method was predicated on a grim vision of developed societies that came as no surprise to the counterculture. Janov came to see the early years of most Westerners as the site of almost continuous suffering, from the agony of birth, through an infancy of unmet physical and emotional need, to a childhood made miserable by mistreatment from parents and other adult authority figures (Janov 1974, 57). Confronted with unbearable suffering, survival mechanisms are mobilized, and the pain is repressed. This repression and its results are what Janov means by 'neurosis'.

6 Later experience will bury this Pain deeper and intensify the 'symptoms' it produces. The progression to adulthood is measured by the ability to repress authentic desires, and in time such repression needs no external coercion. People act in an "unreal" fashion, denying the imperative of their own needs. In the interests of survival, the person splits into "real" and "unreal" selves, into a suffering being of need and desire and a functioning automaton that interacts smoothly with others (Janov 1970, 22-5). The Primal Pain buried beneath our unreal selves becomes the origin of a series of neurotic symptoms, ranging from physical conditions such as asthma, heart problems, migraines, and tics, to behavioural compulsions such as smoking, alcoholism, phobias, and seemingly irrational actions. The cure was to 'primal', or, as Primal discourse came increasingly to put it, 'to feel'; intellectualizing about the nature and origins of neurosis was a waste of time.

3. Primal Therapy: An Amalgam and a Critique of the Ideologies of the 1960sCalifornia Screamin' 
7 Primal Therapy's roots run much deeper than the 1960s, essentially originating in the slow process of revaluing feeling that began in Britain towards the end of the seventeenth century. Nonetheless, the 'discovery' and development of Primal Therapy in the 1960s and early 1970s was in several ways the articulation, in a clinical context, of the contemporaneous countercultural revolution driven by the radical young. Curtis Knecht, who entered the Primal Institute in 1973 and qualified as a primal therapist before becoming a severe critic, has pointed out "how well Janov's promises matched... the political and cultural forces of those times" (Knecht 1991). The connection between Primal Therapy and the counterculture made by this paper is not being offered as a novel insight - Clare and Thompson (1981) make a similar association - but it examines that relationship in a more thorough and precise manner than previously attempted, locating Janov's ideas within a late 1960s turning point for the youth movement, and arguing that this historical 'moment' produced a more nuanced and politicized relationship to the counterculture than is generally allowed for.

8 The geography of Primal therapy's origins was significant: the therapy emerged from the ocean suburb of Venice in Los Angeles, one of the American counterculture's main strongholds, and one more than usually open to ideas that the Establishment would be quick to label "zany" (Lachman 2001, 219; Sutherland 1998, 179). The history of the 'New Age' in the region certainly goes back to the 1930s, and includes the Pasadena branch of the Ordo Templi Orientis (a brotherhood of magicians) and L. Ron Hubbard's 'religion' Scientology (Davis 1990, 57-62). Primal Therapy is rigorously materialist, but Southern California was full of people who had been 'prepared' by such developments to listen to unorthodox ideas. No doubt the area's radical traditions helped too: according to Anderson, the Communist Party was strong in the region in the 1930s and 1940s (Anderson 1996, 12), and the 1970 Weather Underground bombing campaign was particularly active in Southern California (Kimball 2000, 224). Out of this countercultural incubator emerged a type of psychotherapy which incorporated several key 1960s themes: liberation, inter-generational conflict, irrationalism, valorization of childhood, authenticity, violence, and the role of youth as the standard bearers of the revolutionary movement against the counter-revolutionary forces of reformism.

Liberation

9 "One thing I can tell you is / You got to be free" sang the Beatles in 1969, and more than any other idea the rhetoric of liberation dominated the counterculture. The 'long boom' of the post-war capitalist economy freed young Westerners from the economic anxieties experienced by their parents' generation, and this freedom paradoxically resulted in mass opposition to the society (and often the economic system) that seemed to have successfully provided for its citizens' material needs. Herbert Marcuse spoke for many in An Essay on Liberation (1969), a call to end an old society that imprisoned the minds and bodies of its citizens. Not everyone agreed with Marcuse that socialism was sufficient or necessary for liberation, but countercultural calls for freedom from the old order were common. Baby-boomers called for liberation from sexual constraints, from work, from drug laws, from adult authority, and from being either victim or benefactor of racism (see Richard Neville's 1971 book Playpower). The desire for liberation from adult authority had begun in the 1950s, seen in the romanticizing of figures such as the 'juvenile delinquent' in films like Rebel Without A Cause (1955). The political struggle began with the Civil Rights movement, which inspired Bob Dylan to ask "How many 
roads must a man walk down before he's allowed to be free?" By the late 1960s that struggle seemed to have broadened into an indiscriminate opposition to almost any imaginable limitation on freedom. But Primal Therapy seemed to envision a deeper form of liberation: freedom not from external constraints but from who you were, or thought you were, the promise of liberation "from our past" (Janov 1974, 280).

'I heard something 'bout my ma and my pa'

Liberation was often seen as freedom from the world built by one's parents. The 'baby boom' following the Second World War created a demographic group which, becoming teenagers in the late 1950s, influenced social ideas and culture through its spending power in "the new technological high-wage society" (Marwick 1996, 123).The 1960s was characterised by antagonism between this group, who saw themselves as the vanguard of the countercultural revolution, and the generations represented by their parents: "in the eyes of many of the young, the older generations had blown it, living by outmoded codes and traditions" (Doney 1981, 116).The adults who won the war had chosen to trade the exhilaration of victory for the stifling conformity of the 1950s - the 1960s would kill off the world they had built (Green 1999, xi). The Primal Scream is dedicated to Janov's patients and the "youth of the world - the real hope of mankind." Janov's theory, that mental illness is traceable to parental malfeasance and neglect, breathes deeply in this atmosphere of inter-generational conflict: neurosis is (chiefly) the product of parents allowing children's needs to go unfulfilled, so when something has gone wrong parents are to blame: unloving parents were seen as "a child's executioners" (Janov 1974, 272). Laying the burden of guilt for mental illness at the feet of parents was in line with the accusation made by baby boomers that the appalling state of the world was the fault of preceding generations. The innumerable words of anger and anguish screamed at 'mommy' and 'daddy' inside the Primal Institute's sound-proofed walls expressed the feelings of far more than just those undergoing Primal Therapy. Janov, Laing and other countercultural ideologists stressed that parents too were victims of the society they were seen to represent; it is questionable how far those influenced by them chose to remember this shared victimhood.

Beyond Reason

11 Primal Therapy's guiding principle, the aggressive rejection of reason and rationalism, is repeatedly stressed: "The disease...is the denial of feeling, and the remedy is to feel" (Janov 1970, 385). Janov quotes a patient who encapsulates Primal Therapy's position on the uselessness of abstract theorizing: "Whereas in [my previous] therapy I would intellectualize and verbalize - in short, bullshit - for the therapy hour, now I spend as much time as I need feeling my Pain" (220). Janov's anti-intellectualism is a complex matter, but its basic form is an emphasis, contra the whole idea of psycho-analysis, on emotional experience and not intellectual understanding as the key to the ending of neurosis, and a belief that Western societies have emphasized the rational against the affective with debilitating consequences. This belief was at the core of much countercultural ideology. The Daily Telegraph, a conservative British newspaper, lamented in 1971 the alternative society's denunciation of "Reason and calculation" (qtd. in Green 1999, 372), sensing that this rejection was another refusal to accept the authority of the older generation. Countercultural irrationalism grew from complex roots: the philosophy of Zen, which entered the cultural mainstream through the Beats, was one source. D. T. Suzuki's 1959 Zen and Japanese Culture lamented the fact that the cultured world is artificial and ineluctably corrupted by ideas, while Paul Reps, another 
1950s Zen conduit, approvingly quoted the Buddha's adage "The ultimate truth is not even to think" (Reps 1971, 131), while in Jack Kerouac's The Dharma Bums (1959) the character Japhy Ryder advises his companions to climb "like Zen....Don't think. Just dance along" (1994, 48).There were many other sources of distrust of the intellect, and meditative calm was far from the minds of the Yippies (Youth International Party), whose leaders, Abbie Hoffman and Jerry Rubin, attempted to turn spontaneity into political action: "Act first. Analyze later. Impulse - not theory - makes the great leaps forward" (qtd. in Gair 2007, 130). In similar vein, Allen Ginsberg, writing in 1955, had valorised the idea of responding to the suffering caused by Moloch-capitalism with a Howl of rage and pain, expressing but transcending intellectual responses by turning them into physically expressed emotions. Walt Whitman's "barbaric yawp" $(2003,2189)$ is an important progenitor of Ginsberg's Howl, and it is significant that the Dada-ist Tristan Tzara covered one of the pages of his 1920 Dada Manifesto with two hundred repetitions of that word (Tzara 1963, 75). Tzara positioned himself as pro-spontaneity, anti-intellect, and anti-family, and in Dickstein's account, the Beats welded Dada to the more substantial political themes of the 1930s (1997, 12), launching some of those countercultural trends that made possible Danny's scream, Janov's interpretation of it, and the therapy based around it and its successor shriekings. In replacing Freud's 'primal scene' of parental copulation with a cry that pointed to a modality as far as possible from 'analysis', The Primal Scream announced the arrival of countercultural irrationalism in the (padded) therapy room; indeed, the title of Janov's first book indicated the curative method he devised, pointed to some of the cultural preconditions of Primal Therapy, and gave the English language a phrase that has proven highly popular. ${ }^{\mathrm{ii}}$

'Hey, Mr Tambourine Man...'

12 Janov saw adulthood as the final stage of the child's loss of contact with their real self: socialisation removed one further and further from one's authentic physical needs. While Janov saw actual childhood as a site of pain, his vision of the potential of the healthy child to develop by following their needs, at their own pace and uninhibited by adult expectation, was in a tradition of Romantic idealisation that reached its apotheosis in some parts of the counterculture. Such idealisation could be seen in the naked children playing in the fields in Woodstock (1970), while following the whims of childhood in gleeful contradiction of adult norms was the implicit tone of the Merry Pranksters, whose exploits were recorded by the journalist Tom Wolfe (1984). The innocence of infancy was seen by some as a figuration of the purity of perception required to cleanse the prejudices and self-deceptions of adulthood: to "consciously regain the simplicity and wonder of childhood [w] as a perceptual prism for reclaiming a society wracked by civil uprisings and war abroad" (Braunstein 2002, 252).Children were valorised because their worldview was as yet uncorrupted by the compromises and self-consciousness of maturity; they epitomised the lack of preconception that was essential for honest interpersonal relations. Janov succinctly reflects the wider countercultural position: while their real self is jeopardised by social adjustment, children "still have a vitality and reality about them that is not crushed for many years" $(1974,277)$ so it is not surprising he felt that "[b]eing the baby frees the adult" (193).

'Being Real'

Such a valorisation of childhood "reality" was in line with the feelings of many young radicals, who considered authenticity to be missing from the mainstream world; in 
accordance with such ideas, Janov promised his patients access to their real self, their genuine feelings. This idea of 'being real', crucial in the ideology of the Primal Institute, had a long presence in American culture, predating the 1960s emphasis. Henry David Thoreau, for example, was so repulsed by the avaricious and alienated throb of America in the mid-nineteenth century he removed himself for two years to a self-built log cabin next to Walden Pond. "Be it life or death", he opined, "we crave only reality" (Thoreau 2003, 1859).Discussing the motivation for this removal, he mocks the "lives of quiet desperation" (1810) endured by the conformist majority. Influencing the development of this theme in the 1960s was the hatred of "phonies" $(1951,19)$ felt by Holden Caulfield, the prototypical alienated teenager of J. D. Salinger's The Catcher in the Rye. The influence of French existentialism combined with literary fiction and the hippy ideal of 'being straight' to make being 'true to one's self' an important part of the ideology of alternative living, and contempt for the 'unreal' represented a further way of announcing one's superiority to one's parents. Throughout The Divided Self (1960), R. D. Laing was clear and direct in his championship of the 'true self', while at the same time, the young of Paris were calling for a life in which the self was totally engaged in activity, a life without 'dead time', 'ennui' or holding back from experience. A commitment to what was seen as a challenging and unconventional honesty towards both self and others was a likely part of any psychotherapy emerging from the counterculture in the late 1960s.

Days of Rage

14 The therapeutic 'violence' of Primal work reflected those currents of the counterculture opposed to the notion of resolving the world's injustices through 'peace and love.' In Fear and Loathing in Las Vegas (1971), Hunter S. Thompson stressed the tension between violent elements such as the Hell's Angels, and the acid-dropping students and hippies who abhorred violence, calling a 1965 biker attack on the front ranks of an anti-war march an "historic schism in the then Rising Tide of the Youth Movement" (Thompson 1998, 179). As the 1960s progressed, an important part of the counterculture would attempt to recuperate the violence of such as the Angels for revolutionary purposes. This project was also influenced by revolutionary traditions (anarchism and Bolshevism, for instance) that saw violence as an acceptable and necessary part of the struggle for a new society, as well as the mid-1960s 'turn' of some elements of the previously non-violent Civil Rights movement to an aggressive concept of 'self defence' (the Black Panther Party emerged in 1966).

15 The ongoing violence of the Vietnam War and the extent to which the forces of authority would go to maintain the order that perpetrated it seemed, in the minds of many, to justify a militant response from radical youth. 'Hippy' tactics seemed ineffective: during a 1967 anti-war demonstration outside the Pentagon, the $82^{\text {nd }}$ Airborne Division were faced with female protesters baring their breasts, offering free love in the bushes, and placing flowers in the barrels of their guns. The authorities' response was a brutal night-time attack and the arrest of the demonstrators (Marwick 1998, 545). Such encounters suggested that, when confronted by the power of the state, 'peace and love' was as ineffective as (in Janov's view) the 'gentle' treatment of neurosis by analysis, behaviour modification and anything else short of direct confrontation.

16 By the time Janov was developing a methodology out of Danny's scream, many members of the counterculture had absorbed the lesson that peaceful attempts to impose their radical agenda would not work. In April 1968 the Students for a 
Democratic Society (SDS) protested against the administration of Columbia University's President Grayson Kirk by occupying university buildings and appropriating the sherry and cigars in Kirk's office (Isserman and Kazin 2000, 229). SDS leader Mark Rudd wrote an open letter to Kirk:

There is only one thing left to say. It may sound nihilistic to you, since it is the opening shot in a war of liberation. I'll use the words of LeRoi Jones [the radical AfricanAmerican poet, writer, and activist], whom I am sure you don't like a whole lot: 'Up against the wall, mother fucker, this is a stick-up.' Yours for freedom, Mark. (qtd. in Marwick 1998, 659)

17 At an August 1968 demonstration of 10,000 people in Chicago's Grant Park, antiVietnam War protestors threw bricks and stones at the police; chanting "Kill, kill, kill," the police battered anyone attempting to leave the park, and the violence in Chicago's public spaces lasted until 5am the next day (Marwick 1998, 668-69).

18 From 1969 onwards, countercultural resistance to capitalism sometimes took the form of left-wing terrorism, as groups on both sides of the Atlantic bombed, with varying degrees of ferocity, people and places symbolic of 'the system': the Weathermen (later the Weather Underground) (USA), the Angry Brigade (UK), Red Army Faction (West Germany), and the Red Brigades (Italy) (746-51). Such actions, widely reported by mainstream news media, increased the emotional temperature amongst the young. Just as in the 1790s, another revolutionary decade, the left valorised strong feeling and gave it a political significance (Kimball 2000, 22). The British militants, for example, called themselves the 'Angry Brigade' (knowingly or unknowingly echoing the French 'les enragés') while in October 1969 their American counterparts the Weathermen conducted the riots and destruction of property known as the "Days of Rage." Over 300 people took part in this action, which included the dynamiting of a Chicago statue (Heale 2001, 146).

19 The basic unit of Janov's therapy, 'primals', can be a violent phenomenon, often frightening to those seeing them for the first time, as they involve the full expression of the emotion that was repressed at the time of the trauma. The violence inside the Primal Institute, as patients screamed and punched their way to mental health, echoed the violence on the streets, while Janov aligned his therapy discursively with those who refused to compromise: "Primal Therapy...is revolutionary because it involves overthrowing the neurotic system by a forceful upheaval. Nothing short of that will eliminate neurosis" (Janov 1970, 11). .ii $^{\text {ii }}$

Rejecting Reformism

20 Janov took more than just imagery and the need for extreme measures from the revolutionary left. Explicit and implicit political undercurrents run throughout his first three books. He repeatedly connects Primal Therapy to a wider programme of revolution: "If we can get the youth straight, they will bring about a new society" (Janov 1974, 278).A manifesto produced by Hoffman and Rubin's Yippies shared this assumption that radical social transformation is not to be dictated from above but emanates from personal change. "Everyone becomes a life actor of the street doing his thing," it claimed, "making the revolution by freeing himself and fucking up the system." (Youth International Party 2003, 278)

21 Janov's language and therapeutic worldview seem obviously influenced by Marx and Engels, who argued that mature capitalism produced and depended on the skilled industrial workforce whose collective activity would lead to the overthrow of the 
bourgeoisie and the capitalist system: "What the bourgeoisie, therefore, produces, above all, is its own gravediggers. Its fall and the victory of the proletariat are equally inevitable." (Marx and Engels 1985, 94) Janov's vision of neurotic society producing its own gravediggers is strikingly similar: "Nature's dialectic provides that the conditions of unreality simultaneously produce the necessary conditions of reality. The more suppressive the society, the greater the force suppressed. That force must have its day..." (Janov 1974, 273). iv Many members of the youth movement in the late 1960s saw themselves as the advance party of revolution, and Janov too believed they were the group most receptive to the transformative potential of Primal Therapy: there is a social class "that is ready [to get better] - a class suppressed because it is the enemy of the unreal - the youth" (278). Neurosis was the equivalent of capitalism - each an unreal system striving to perpetuate itself by crushing the real elements in the self or in society. Traditional modes of therapy, such as psychoanalysis, were like reformist political strategies. When Janov asked 'Can we work within the system?' he was applying to therapy a question frequently asked by socialists in the 1960s about politics. He answers ironically that "psychoanalysis works within the neurotic system, and we see what a success it has been" (Janov 1974, 273-6). Janov argued that rather than confronting Primal Pain, psychoanalysts worked to preserve the unreal self (Janov 1970, 209). Writing in 1971, he declared "I am calling for revolution...We must overthrow that system [neurosis] by force and violence" (Janov 1978, 29). Primalling (connecting to the repressed feelings that produced your symptoms) is like the revolutionary seizure of the economic base in socialist theory: it deals with the problem at its root. The confrontational methods of early Primal Therapy were the therapeutic equivalent of militant political action, positioning the therapist as an analogue of the revolutionary forcing on a reluctant society the changes that it needed: the patient's 'unreal self', both product and representative of the old order, summoned just enough authenticity to co-operate with this violent midwifery of the new (this will-toconfrontation is considered in the chapter on Primal Therapy in R. D. Rosen's Psychobabble [1978]). Janov's repeated designation of repression and neurosis as "the system" drew on the terminology of the radical young, for whom "opposition to "the system"" (Heale 2001, 140) was a rallying cry. In a 1970 pamphlet ("Bring the War Home"), for example, the Weathermen identify "the system" - imperialism, white supremacy, male supremacy and racism - as their enemy (2003, 379-80).

22 For Janov, Primal Therapy threatened the existing economic order because it unpicked the lock of repression that capitalism depended on. In a straightforwardly Marxist way, he characterises capitalist society as based on the exploitation of one class by another, and uses the term "control" to describe the social equivalent of the personal repressive mechanism: when society is organised into exploiter and exploited, he argued, "control" is necessary to keep the exploited from "expressing and securing their needs" (Janov 1974, 201). He explains that while this control may take the form of brute force, the most subtle method is to convince people to control themselves. Just as individuals bury their authentic needs, exploited social groups adjust to and accept the situation where their collective needs are unmet. They learn not to make demands workers, for example, never considering that their labour gives them a right to part ownership of the factory. (202) Primal Therapy elevates need to the centre of being and jeopardises the internalisation of repression that capitalism depends on: because "it advocates loss of control in its therapy, Primal theory becomes a threat to the entire institutionalization of control" (203). 
In summary: Janov never produced an explicit programme for political action, and the structure of The Primal Scream implies that his therapy was derived more or less directly from the experiential encounter with the supra-rational realm of intense non-verbal emotion. However, the creation of Primal Therapy should also be seen as a culturally and historically determined meeting of some of the most important ideological tendencies of the late 1960s with existing psychotherapeutic methods and traditions. The primal discourse, as it was embodied in Janov's first three books, embodied a series of decisions about therapeutic theory and practice that were mediated by the geographically and historically specific culture of late 1960s Southern California. Where, then, did these cultural forces take Janov? To answer this question we need to briefly discuss his relation to the founder of modern psychotherapy, Sigmund Freud.

Back to the Future: Janov and Freud

24 Although they were not the first to therapeutically induce catharsis (Forrest 2000, 97), in the 1890s Freud and Josef Breuer began to use hypnosis to elicit traumatic memories from patients. They came to believe that these previously repressed memories were the basis for the patients' "hysterical" symptoms and that the process of "abreaction" would free them from their suffering (Breuer and Freud 1955). In circumstances that remain controversial, Freud abandoned most aspects of this trauma theory of neurosis, arguing that the frequent scenes of adult sexual abuse that were 'recalled' were typically phantasies, and that neurosis could only be alleviated by a meticulous analysis of the patient's progression through the stages of the sexual drive. Writing in 1932, Freud recalled that during the period when his therapy

was directed to discovering infantile sexual traumas, almost all my women patients told me that they had been seduced by their father. I was driven to recognize in the end that these reports were untrue and so came to understand that hysterical symptoms are derived from phantasies and not from real occurrences. (Freud 1973b, 154)

25 For the later Freud, it is "the early efflorescence of sexuality" that generates the "impressions" that act "like traumas" on the child's immature ego, which responds to the "emotional storms" thus created with repression (Freud 1973c, 182). The trauma theory occasionally flashes into Freud's later writing (Freud 1957; Freud 1973a, 126-7), but true to his new direction of the late 1890s, he usually worked with narratives of the child's journey through the sexual stages.

Freed from a belief in his patients' victimhood, he developed a fundamentally conservative view of the relationship between the individual and society, stressing the necessity of some degree of repression in the interests of societal adaptation (1973c, 182). Freud proposed it was "impossible to give [the child] liberty to carry out all his impulses without restriction." He accepted that education and self-control would "bring the child into line with the established order of society" and argued it was illegitimate for psychoanalysts and educators to concern themselves with 'liberating' the educational system "from the prevailing demands of society" (186).

The cultural circumstances of the late 1960s pushed Janov in the direction of a complete break with these tendencies, but the connection to early Freud was noted by one associate of the Primal Institute, who claimed Primal Therapy recaptured the lost tradition of early Freudianism (van Doren 1980-1). For Janov, sexual abuse by parents and other adults is typically real, and the development of the sexual 'instinct' is not in itself a problem. Trauma is caused by cruel punishments, parental indifference, and indeed anything that signals to a child their parents' lack of love. 'Analysis' of causes 
and symptoms is, like all intellectualisation, useless. Jacques Lacan's phrase 'the optimistic days of catharsis' suggests another sense in which Primal Therapy was a product of the 1960s. Lacan meant that in the 1890s Freud optimistically believed that trauma could be resolved by some kind of direct repetition of itself, but would later argue that healing could only take place away from the site of the wound (Lacan 1979, 50). Lacan was happy with psychoanalysis, with a practice that "has only a single medium: the patient's speech" (Lacan 1980, 40). Janov, in the spirit of those in the 1960s who felt that a truly fundamental solution to humanity's problems was at hand, went back to the 'optimism' of catharsis and the authenticity of the non-verbal. In the same spirit, he saw his patients' refusal to reintegrate into their pre-Primal 'normal' lives as evidence that they had been cured. Society was 'sick', it was producing 'sick' individuals, and at its fullest extent Primal Therapy would 'cure' the social and educational structures that Freud believed it was not the business of the therapist to be concerned with.

of course, Janov was not the first person to have doubts about Freud's later ideas and methods, and he was influenced by many other psychotherapists, both his predecessors and contemporaries. A seminal influence on psychotherapy in the 1960s was the renegade Freudian Wilhelm Reich. Reich had gone beyond talking about trauma and went deep into the body in order to dissolve its defensive armour, although like Freud he still located the roots of neurosis in the "differentiation between accumulation and discharge of sexual energy" (Reich 1968, 176, 123). After Reich's death, a group of postReichian psychotherapists, influential in the countercultural milieu in which Primal theory was created, saw themselves as fighting against 'the betrayal of the body' (Lowen 1967, 269). Other therapeutic approaches were also pointing in the direction taken by Janov. Before its legal suppression in the late 1960s, Stanislav Grof had been using LSD to promote the reliving of early experiences. Primal Therapy took the idea of (drug-free) regression to past traumas while emphasizing the emotional component, or 'feeling' - perhaps influenced in this by Gestalt therapist Fritz Perls, who would invite volunteers from his "lecture-demonstration seminars" to sit in a chair at the front of the room (Perls 1971, 78-81). Perls liked to use this 'hot seat' to break down defences and promote crying (Kripal 2007, 163).

Whatever the precise ingredients Janov turned into Primal Therapy, all of the elements had almost certainly been practiced previously by other 'alternative' psychotherapists, some of whom have claimed they were already developing similar therapies when the publication of Janov's book led to the association of this psychotherapeutic practice with one name only. Whether Janov is seen as Primal Therapy's creator or merely as the man who gave it shape, public presence and an alluring label, our argument is the same: forces at work in the late 1960s would have led any psychologist in tune with the counterculture to select some elements and reject others from the huge variety of approaches they would have been aware of professionally. Regression, the stress on powerful emotion, focusing on the consequences of parental misdeeds, the rejection of 'talking cures' - all were consonant with some of the counterculture's most powerful tendencies. The dramatic form of Janovian therapy - which began with 24 hours of isolation and moved into a three week 'intensive' of almost daily open-ended Primal sessions - was in tune with its revolutionary credentials, its desire to smash neurosis in an uncompromising confrontation. However, Janov saw himself as doing more than just articulating countercultural ideas. He sought to help 'the movement' by critiquing it, 
by pointing out the ways in which it was undermining itself through perpetuating neurosis under the guise of liberation.

The Revolution Rescued

In The Primal Revolution Janov is explicit: the rapid adoption of Primal Therapy will accelerate the overthrow of the existing social order and the capitalist system. The psychological revolution embodied by Primal Therapy would be a precondition of wider social and economic revolution. People who throw off their neuroses "will neither produce nor tolerate life under unreal conditions" (Janov 1974, 278). Echoing Gramsci, he declared social revolution was on the agenda: "the transformation of the members of society is inevitably the transformation of that society. That world is within our reach because in an unreal society, the simple truth is revolutionary." (285) However, should radicals bring about a revolution but fail to overthrow their neuroses, the danger is a "new social system [would] be superimposed on sick people", who "corrode" the "essence" of the new society (Janov 1974, 277-8) Jenny James, founder of radical Primal communes (unaffiliated with Janov) in London, Ireland, and Colombia, makes a similar point in more demotic language: "Who in their right senses would want to buy the philosophical goods offered by the miserable, tight, rigid, fucked-up people...who fill the ranks of so many left-wing organizations?" (James 1980, 47). In other words, Primal Therapy's contribution to countercultural revolution is that it prepares the minds of the populace for the enormous shifts that society must make in addition to correcting those aspects of the counterculture that were, Janov believed, counterrevolutionary because they represented neurotic symptoms. For example, while he believed that women's liberationists were fixed on the right social problems, Janov wondered whether the women working for gender equality were projecting their hatred of men onto the world (Janov 1974, 276). Political success depended on the revolutionaries knowing what was real and what were neurotic symptoms disguised as liberating activities.

31 Significantly the gestation of Primal Therapy took place at a contradictory moment within the counterculture itself. The impetus to produce radical change was still present, but chastened by the events that marked 'the end of the 1960s': the San Francisco Diggers' 'Death of the Hippy' mock-funeral (October 1967), the failure of the 'new French Revolution' (May 1968), the murders by the Manson family (August 1969), the death of Meredith Hunter at Altamont (December 1969), and the Beatles' split (1970). The first wave of the counterculture "surged forward, crested, and brought America to the rip tide of 1968,' (Anderson 1996, xviii) but after the failures met by this 'first wave', various forms of re-assessment were inevitable. Janov belonged to those strands of the counterculture that refused to abandon the earlier commitment to social change, so sought to critique radical ideology and lifestyles in order to plant the seeds of eventual success in the future. Anderson quotes a participant who identified the counterculture as "a grand geodesic dome fitted together from pieces of Marx, Freud, Zen, Artaud, Kesey, Lenin, Leary, Ginsberg, Che, Gandhi, Marcuse, Laing, Fidel and Lau Tzu" (1996, xvi); the counterculture had created a mosaic of liberation and Janov rejected some of its pieces. He believed seeking freedom through sex and drugs, or escaping from bourgeois rationality and materialism into the occult, spirituality, or religion were all expressions of Pain. Therapeutic and political success depended on eliminating or at least limiting such symptoms. What linked undesirable elements of the counterculture was the quest for a phoney liberation: people who dress in "funky, wild clothes", indulge in promiscuous sex and indiscriminate drug taking, or even "take 
off for somewhere whenever the urge hits them" are probably "acting out a freedom they can't feel" (Janov 1974, 231).

The Reality Trip

32 'Free love' had been an important part of the counterculture and most radical psychologists believed that sexual liberation was necessary to therapeutic success. The society that rendered us neurotic also destroyed our sexuality, so ending neurosis meant rediscovering sexual freedom as both means and result. R. D. Laing bemoaned our alienated sexuality $(1967,46-7)$, while his occasional associate David Cooper saw sexual liberation as a necessary part of anti-psychiatry (Cooper 1976, 57). Janov, on the other hand, saw insatiable sexual cravings as a product of denying children love (1970, 24) and promiscuity as the mistaken idea that the love withheld by parents can be fulfilled as sex (285). Writing in 1972, he suggested that homosexual patients arrive at the Institute looking to relieve a seemingly unrelated tension, but found that the therapy unexpectedly eradicated their homosexuality $(1974,85)$. This is not to imply that Janov should necessarily be seen as homophobic - the Primal Institute has encouraged repressed gay people to live out their sexuality - or that his position on sexuality was similar to that of traditional Christianity or later conservative critics of the 1960s. Minnie Warburton's 1979 novel Mykonos, part of the literary response to Primal Therapy, is emblematic in representing sex as both the ultimate acting-out of Primal Pain and an important part of a healing relationship (Warburton was associated with the Primal Institute in the 1970s; see also Janov 1970, 284-5).

33 From the very beginning, those entering Primal Therapy had to agree to give up all recreational drugs, including nicotine. Although Janov, as part of his high valuation of the young, claimed that 'their' cannabis was at least a drug that stimulated rather than repressed feeling, he believed it dangerous when taken during Primal Therapy. LSD, which, he came to believe, disrupted the gating system that kept Primal Pain unconscious, was even more dangerous. Primal Therapy removed the need for drug use. To continue using drugs instead of to feel was, Janov believed, the route not to social transformation but to personal disaster (Janov 1970, 351, 366-7, 422).

34 It is widely argued that the counterculture was at least partly based on a desire amongst the young for 'transcendence', for an escape from the constraints not only of mid-twentieth-century conformity but also of Enlightenment rationality. Janov offered such an escape, but without spirituality; natural life was rich enough, once freed from the constraints of neurosis. One of the charges brought against the old society was that, as Howl attempted to show, it suppressed one's spiritual self. Spiritual fulfilment, many came to feel, might be achieved through Eastern religions, through Hindu/Buddhist meditation systems, for example, or the Zen irrationalism previously discussed. Janov claimed that meditation was a practice that detached you from your Pain instead of connecting you to it. The experience of oneness and relaxation is in fact "a state of total unreality," and he cites a patient in Primal Therapy who suffered a "complete breakdown," despite practising transcendental meditation as a Vedanta monk for twelve years (Janov 1970, 222). In contrast, R. D. Laing's encapsulation of the 'moment' of 1967, The Politics of Experience and The Bird of Paradise, is full of the concepts of Eastern religion, whose idea of 'emptiness' is seen as an essential aid in the Western quest for the healed self. Despite Janov's own anti-rational rhetoric, a paradoxical rationalism underlies Primal Therapy. His picture of the post-Primal patient was of someone acting reasonably for the first time. British dramatist James Saunders sensed the importance 
of this emphasis: his 1977 play Bodies debates the desirability of a Primal revolution, after which "all (would) be light and reason" (Saunders 1979, 64), seeming to prefer the 'neurotic' status quo to an antiseptic and emotionally purged Primal world.

It was with such a critique that Janov hoped to steer the counterculture towards revolutionary success. He was not alone in such thinking. The late 1960s saw the growing realisation amongst radical youth that the 'permissive' practices of the counterculture were not necessarily revolutionary: they could be counterrevolutionary lifestyle diversions or even tools of unwitting self-destruction. We turn now to two 1970s British cultural texts addressing the same agenda: what might happen to a counterculture unable to deal with, or even to critique, its own neuroses?

3. Primal Ideas in Cultural ProductsThe Primal Therapy Concept Album: John Lennon / Plastic Ono Band

After undergoing Primal Therapy themselves, John Lennon and Yoko Ono created the 1970 album John Lennon / Plastic Ono Band. Lennon had paid for Janov to fly to the UK to administer the therapy, which led to Lennon attending the Primal Institute from June to September 1970 (Wenner 1981, 131). Lennon saw Primal Therapy and screaming as fitting a predisposition already present in popular music and his own work. In a 1969 interview, he playfully suggested he had pre-empted Ginsberg by calling his school newspaper "the Daily Howl." In the same interview Lennon identified the "pure sound" of "awopbopaloola" (from Little Richard's 1955 "Tutti Frutti") as a new direction for his song writing (Miles 1995, 71). Lennon expressed his ambition to extend this lineage of expressive communication outside semantic coherence by starting from Little Richard's screaming and "just eliminating the song bit and elongating the howling bit..." (Miles 1995, 74). At a concert before he had undergone Primal Therapy, Lennon introduced 1969's "Cold Turkey" with the words "I'm going to sing a song about pain." Later he summarized: "So pain and screaming was before Janov" (Wenner 1981, 131).

Lennon's first solo album offers a critique that concurs with Janov's. Drawing on his personal experience, Lennon portrays the counterculture's failure as the inability to deal with repressed feelings. As one of The Beatles, he was part of a utopian project that sang "love is all you need" (Lennon and McCartney 1967) to save humankind. By 1970, with The Beatles disbanded, Lennon sang "I don't believe in Beatles" (1970a) and refused "the notion that [a] rock group...could change the world" (Doney 1981, 107). "I was the Walrus [a character from an earlier song] / But now I'm John" (1970a) sums up Lennon's post-Primal perception that his identity had become predicated on the Beatles myth, and the mistaken belief he was the emissary of social change. Lennon traces this need to be "always playing a part" (1970d) back to the trauma of parental abandonment: "my Ma and Pa...didn't want me so they made me a star" (1970b). In Primal terms, feeling unloved by his parents caused Lennon to become a pop star so that everyone would love him (Janov 1970, 28). His identity as one of the Beatles becomes almost synonymous with the Primal 'unreal self' and, torn between the two, Lennon pleads "Who am I supposed to be?" (1970c) Lennon professes to have felt the Pain that motivated him to be a countercultural celebrity: "Now that I found out [i.e. seen through the claims of the counter-culture] I know I can cry...feel your own pain" (1970b). Lennon argues 'free love' is a social anaesthetic to "Keep you doped" (1970e) and drugs are there to "fool you" (1970b), but his most searing indictment is reserved for popular music. He does not believe in John Lennon, Beatle and countercultural prophet: "I just believe in me / Yoko and me / And that's reality" (1970a). Similarly, 
Janov quotes a post-Primal patient: "Maybe I expected to become my neurotic fantasy that someone special who would finally be loved and appreciated. All there seems to be is me..." $(1970,105)$. Breaking through the fashionable illusions his Pain made him vulnerable to, Lennon has finally found himself and learnt how to see the world as it really is. The counterculture was right to challenge a society in which "They hurt you at home and they hit you at school" (1970e) but the nature of the challenge meant inevitable failure, forcing the authentic individual to retreat to the fastness of himself and his one true relationship.

The Stillborn Revolution

Something very similar to Janov's model of Primal Pain can be found in Martin Amis' Dead Babies (1975). Direct influence is plausible, as Amis uses the phrase "primal scream" in a 1980 book review, but it is also possible that he was simply influenced by some of the same cultural factors that determined the nature of Janov's therapy. In either case, the closeness of some of the characters in the novel to Primal case studies underlines the pervasiveness of these ideas in the first half of the 1970s. The novel features a weekend-long house party at Appleseed Rectory where one of the characters is stalking and murdering the other partygoers. Dead Babies is set in the near future, after a successful 'sixties' social revolution has created a world dominated by the ideas of the young (Amis 1984, 166). In particular, the sexual revolution has reached demented levels of frankness and precociousness: "They're blowing each other in the fuckin [sic] playpens" (135-6). Attending the party is a group from the United States, who herald the countercultural revolution taken to an even greater extreme: "Things happen faster in the States" (136).

One of these Americans, Skip, seems to be a fictional exemplar of Primal themes. Skip is presented as a figure whose violence, drug-taking and promiscuity mask and condense his Primal Pain. The revolution Skip represents is fatally compromised by his inability to feel this Pain, as his trajectory through Dead Babies shows. He was raised in the American South, a region culturally charged with the ambience of reaction (see the 1969 film Easy Rider). Skip's father, Philboyd, embodies the stereotype of the Southern redneck, subjecting his son to rape and "motiveless beatings." As Janov would have expected, too young to cope with this trauma, skip buried it in his unconscious behind a façade of "apparent sanity" (Amis 1984, 65). Denied Philboyd's love, Skip pursues the satisfaction of his needs symbolically (Janov 1970, 23). He starts taking drugs, and, seeking the approval of others, he performs "menial sexual chores" for older boys. Skip will "do anything" for attention (Amis 1984, 65-66), and Amis's representation of promiscuity, homosexuality and drug-taking as the result of deep-rooted Pain mirrors Janov's resistance to acknowledging them as legitimate liberating activities.

Skip's "sexual chores" and drug-taking are met with more violence: "Philboyd clubbed his son round the kitchen with a frypan for three-quarters of an hour." Eventually Skip, in self-defence, hits his father, who proceeds to kill Skip's mother: "Skip's life had fallen apart all around him" (Amis 1984, 66). Skip represses the Pain of losing his mother, becoming a "blank figure...silent, unreflecting"; he stops acknowledging the past, burying his Pain so that Marvell (another American character) can say "I don't think he thinks about his earlier life at all now" (67-68). Janov might diagnose Skip as having reached the critical point where the build-up of Pain has left him more unreal than real, completely suppressing "the real needs and feelings of the organism" (Janov 1970, 24). The vocabulary used to describe Skip - "hard and metallic" 
(Amis 1984, 158), "dead, undersea eyes" (93) - emphasizes his retreat from the 'real' world of human feelings. Skip's neuroses grow as extreme as his Primal Pain, and manifestations of his anger towards Philboyd include hitting a cow with a brick, regularly using "heartbeat-accelerators," and indulging in sexual relations of myriad permutations $(22,64,92)$. Burdened by trauma, the slightest mention of his past creates a violent reaction: "Want to see someone go really wild? Ask Skip about his father" (Amis 1984, 68). This is how Johnny, the Appleseed Rectory murderer, organizes Skip's suicide: driving back to the Rectory, Skip finds a letter from Philboyd planted in the Chevrolet, asking Skip whether the two can rebuild their relationship. This causes the Pain to build up so strongly that Skip drives the car off the exit-route ramp at $135 \mathrm{mph}$, killing himself and his passengers (both Janov [1974, 54] and Jenny James [1980, 1] refer to the car crash as an example of how fatal unaddressed Primal Pain can be). Janov's patient Anne offers a useful comparison for Skip's psyche at this moment: plunged by a neighbour's warmth into the emptiness of her own life, she breaks down at this manifestation of the "kindness, reassurance, simple humanity" she never knew as a child (Janov 1970, 33).

Skip's suicide seals Dead Babies' portrayal of the counterculture's futurelessness. The retreat of the novel's characters into Appleseed Rectory the better to pursue their pleasures symbolises its hedonistic insularism. Marvell believes the sexual revolution has permitted the enjoyment of sex without emotional commitments: "Sex is something your body does, like eating or shitting." (Amis 1984, 136) Repeated injunctions against 'love' as the panacea for the world's problems suggest that personal pleasure has eclipsed the radical agenda of social change: "love can't mean anything any more. That's hippie talk. Love's through. Love's all fucked up...Babies,' he muttered. 'Dead, dead babies'" (137). The symbolism of identifying the counterculture's ideological positions as "dead babies" - a new generation dead before it had the opportunity to live - amplifies the novel's suggestion that unless the Primal Pain of 'liberated' humans is addressed, it will inevitably be passed on to succeeding generations. If the symbols of liberation are merely neurotic symptoms, are acts of countercultural transgression follies that lead to self-destruction? The Appleseed Rectory murders suggest that they are. Ignorant of their Pain, the characters in Dead Babies are dead to their real selves, as registered in the novel's last line, a physical description of Johnny the murderer: "his green eyes flashed into the dawn like wild, dying suns" (224). The pessimism about the 1960s in John Lennon/Plastic Ono Band left room for hope that individuals could become 'real' through Primal Therapy. Dead Babies declines to consider any such hope.

4. Primal Therapy since the 1980 s

42 Since the mid-1980s, Primal-style therapies have often been repudiated as the New Age excesses of a misplaced faith in emotion and irrationalism..$^{v}$ Described as an "uglier spinoff" of Primal Therapy, Rebirthing was, Martin Gardner has claimed, "a crazy New Age technique started in the 1970s by...Leonard Orr. The therapy consists of wrapping a patient in blankets to simulate the mother's womb, then pushing pillows onto the patient's face to arouse feelings of labor contractions." Gardner goes on to discuss the case of Candace Newmaker, a 10-year-old from North Carolina, who died of asphyxiation following an 'attachment therapy' session. As the name suggests, attachment therapy seeks to heal those parental-child bonds that, for whatever reason, have become attenuated. Although never directly stating a lineal sequence, Gardner's 
implication is that Janov's “'primal scream' techniques” inspired Leonard Orr's Rebirthing, which in turn produced attachment therapy (Gardner 2001, 17-19).

Candace Newmaker's treatment was undertaken after the therapist judged her "to be suffering from 'attachment disorder,' characterized by her inability to form loving relationships" (Gardner 2001, 17-19). The popular American television series Crime Scene Investigation featured attachment disorder therapy/Rebirthing in the episode "Overload," televised in 2001 on the CBS channel, and the events portrayed shared profound similarities with Newmaker's case (see also the Law and Order episode "Born Again"). Crime Scene Investigators Nick Stokes and Catherine Willows probe the death of fourteen-year-old Dylan Buckley during therapy. Dylan was instructed by his psychiatrist, Dr. Sapien, to lie on the floor in a fetal position, and was wrapped in a blanket symbolising the birth canal. By fighting his way out and conquering his fear of suffocating during birth, Dylan would, Sapien posited, overcome the resentment felt towards his mother for putting him through that trauma. The flashback at the episode's end implies the clumsiness of such 'rebirthing': Sapien and Dylan's mother resist too forcibly his attempts to break out of the blanket, accidentally causing his death.

Contemporary perceptions of Primal Therapy are illuminated by the genealogical link Gardner draws between Rebirthing and Primal Therapy. This family resemblance is also noted by prominent biologist Steven Rose, who calls the psychotherapy of "Primal Screaming" a "form of 'rebirthing'" $(1998,55)$, and by Canadian psychologist Tana Dineen, who suggests Newmaker's attachment disorder therapy was "a New Age version of ideas...Arthur Janov incorporated in his Primal Therapy" (Dineen 2000). The real relationships between Primal Therapy, Rebirthing and attachment disorder therapy are not easy to decipher, but both Orr's approach and the kind of 'regression' work that led to the Newmaker tragedy are often considered to be the offspring legitimate or illegitimate - of Janov's theories. Such attempts to re-experience very early trauma are now sometimes seen as embodying irresponsible New Age irrationality. Gardner, Rose and Dineen bear witness to one way in which Primal Therapy is now understood, but as far as we are aware no convincing evidence links Janov or Orr with such shocking 'therapeutic' violence.

5. Conclusion

Neither 'Arthur Janov' nor 'Primal Therapy' are represented on the website of the magazine Psychology Today. This absence from a huge online source is neatly symbolic of the therapy's broader contemporary obscurity, especially as there is one nontechnical use of the phrase 'primal screams'. Given that Janov's critics do not dispute his impressive sales for The Primal Scream (Clare and Thompson 1981, 121), that one of the most famous people of the twentieth century went through this therapy (dedicating an LP to it), and a song inspired by Janov's writings has been both number three and number one in the British charts, this obscurity is puzzling. Primal Therapy initially enjoyed a success almost as dramatic as the cure it claimed to effect: from the sometimes impoverished followers of 'sixties' guru Bhagwan Shree Rajneesh (Osho 1983) to the excruciatingly fashionable middle-class inhabitants of Marin County satirised in Cyra McFadden's The Serial (1978, 12-13), Primal Therapy became for millions of people a cultural reference point, a subject of discussion at parties, and in some cases a personal practice. 

insignificance in the following decades. Many would argue that this is because of Janov's failure to demonstrate his claims about the therapy in a way that satisfies scientists like Steven Rose, but one can also observe a striking shift in which the successors to the part of the therapeutic and cultural spectrum that welcomed Primal Therapy are now suspicious of cathartic emotion. Representative of this trend towards 'reformist' methodologies avoiding direct experience of emotional pain, the influential Post Traumatic Stress Disorder specialist Peter Levine argues it is dangerous to excavate past feelings because they can lead to even greater mental trauma when being revisited. This parallels shifts in politics that include the post-1970s eclipse of the far left. Perhaps because Primal Therapy was so closely connected to the political and social impulses of its era it lacks the ideological underpinnings to interest cultural producers today, who no longer respond to it as Warburton, Lennon, Amis, and Saunders once did. Since the mid-1980s Janov's work has sunk from public view, best known as what it is not, whether that misinterpretation is the focus on 'Primal Scream therapy' (a frequent misdesignation - see Rose 1998, 55; Miller 1999, 80) or its labelling as a form of Rebirthing, perhaps even as the progenitor of the 'attachment disorder therapy' that produced the Newmaker tragedy. Paradoxically, its core assumptions - that neurotic symptoms are the result of buried childhood trauma of a generally non-sexual nature, and that such symptoms can be eased or resolved though some form of 'venting' - seem to have been absorbed into transatlantic mass culture. The Simpsons - an often reliable trans-generational barometer of popular wisdom provides a number of examples. In the episode "I am Furious Yellow", Homer's rages are interpreted by Dr. Hibbert as channelling his emotion and preventing the growth of potentially fatal lumps on his neck; in "Hurricane Neddy" the pacifistic Ned Flanders is encouraged to be angry more often by his childhood psychiatrist Dr. Foster because it is more healthy than his usual processes of suppression. Even in the episode of CSI discussed above, Nick is forced to face the fact that his more than usually fervent pursuit of Dr. Sapien is fuelled by trauma from his personal past. We are not, of course, suggesting that the widespread (if far from universal) acceptance of such ideas is primarily due to the work of Arthur Janov; but we do feel that his now largely forgotten role in changing ideas about emotional expression deserves serious attention and analysis.

This paper has located the construction and reception of Primal Therapy and its brief period of cultural influence in the historical context of the late 1960s and early 1970s. Janov explicitly aligned Primal Therapy with other contemporary revolutionary projects, and his model of Primal Pain shared key features with countercultural ideological positions, while simultaneously offering a critique of those positions as the consequence of repressed personal trauma. John Lennon and Martin Amis created cultural texts sharing Janov's critical perspective on the countercultural revolution, but since the mid-1980s at the latest, Primal Therapy's dwindling imaginative presence in literature and popular culture has shadowed the decline of the political culture it ran alongside. It seems that - in the admitted absence of any robust evidence pointing in either direction ${ }^{v i}$ - commentators are as confident of its worthlessness as they once were of its unique value. Mapping the changing reception of Primal Therapy leads to some interesting conclusions about the way some aspects of 'the sixties' are currently (mis)remembered and to a deeper insight into the ways in which apparently objective 
and professionally arrived at judgments can be determined by the amorphous processes that create cultural fashion.

\section{BIBLIOGRAPHIE}

Works Cited

Print and Online Texts

Amis, Martin. 1984. Dead Babies. Harmondsworth: Penguin. Originally published in 1975.

---. 1980. Rev. of Elvis, We Love You Tender by Dee Presley, Bill, Rick and David Stanley, as told to

Martin Torgoff. Randomhouse.com. http://www.randomhouse.com/boldtype/0702/amis/ excerpt.html (accessed 18 May 2008). Originally published in the Observer August 1980.

Anderson, Terry H. 1996. The Movement and the Sixties. New York: Oxford University Press.

Anon. 2005. Profile: Howard Dean. bbc.co.uk, 12 Feb. http://news.bbc.co.uk/1/hi/world/ americas/2979960.stm (accessed 15 Feb. 2008).

Blake, Paul. 1985. “Feeling Politics.” Primal Institute Newsletter, Jan. 1985: N.p.

Braunstein, Peter. 2002. Forever Young: Insurgent Youth and the Sixties Culture of Rejuvenation. In Imagine Nation: The American Counterculture of the 1960s and 1970s, ed. Peter Braunstein and Michael William Doyle, 243-273. New York: Routledge.

Breuer, Josef, and Sigmund Freud. 1955. Studies on Hysteria. In The Standard Edition of the Complete Psychological Works of Sigmund Freud, trans. and ed. James Strachey, vol. II. London: Hogarth Press. Originally published in 1893-95.

Clare, Anthony W., and Sally Thompson. 1981. Let's Talk About Me: A Critical Examination of the New Psychotherapies. London: British Broadcasting Corporation.

Cooper, David. 1976. The Grammar of Living: An Examination of Political Acts. Harmondsworth: Penguin. Originally published in 1974.

Davis, Mike. 1990. City of Quartz: Excavating the Future in Los Angeles. London: Verso.

Dickstein, Morris. 1997. Gates of Eden: American Culture in the 1960s. Cambridge, MA: Harvard University Press.

Dineen, Tana. 2000. A warm, deadly blanket. tanadineen.com, 2 June.

http://www.tanadineen.com/COLUMNIST/Columns/A\%20warm\%20deadly\%20blanket.htm (accessed 30 May 2008).

Doney, Malcolm. 1981. Lennon and McCartney. Tunbridge Wells: Midas.

Engels, Frederich. 1975. The Dialectics of Nature. In Werke: Karl Marx, Frederich Engels, vol. XX, 305-368. Berlin: Dietz. Originally written between 1873 and 1883.

Field, Andrew, and Devin T. Stewart. 2007. China's Primal Scream. Policy Innovations, 26 July. 
http://www.policyinnovations.org/ideas/commentary/data/primal_china (accessed 15 Feb. 2008).

Forrest, Derek. 2000. Hypnotism: A History. Harmondsworth: Penguin.

Freud, Sigmund. 1957. On Metapsychology. In The Standard Edition of the Complete Psychological Works of Sigmund Freud, trans. and ed. James Strachey, vol. XIV, 105-260. London: Hogarth Press. Originally published in 1915.

---. 1973a. Anxiety and Instinctual Life. In The Pelican Freud Library, trans. and ed. James Strachey, vol. II, 113-44. Harmondsworth: Penguin. Originally published in 1932.

---. 1973b. Femininity. In The Pelican Freud Library, trans. and ed. James Strachey, vol. II, 145-69. Harmondsworth: Penguin. Originally published in 1932.

---. 1973c. Explanations and Applications. In The Pelican Freud Library, trans. and ed. James Strachey, vol. II, 170-92. Harmondsworth: Penguin. Originally published in 1932.

Furman, Simon, Jose Delbo, and Geoff Senior. 2002. Transformers: Primal Scream. London: Titan. Gair, Christopher. 2007. The American Counterculture. Edinburgh: Edinburgh University Press. Gardner, Martin. 2001. Primal Scream: A Persistent New Age Therapy. Skeptical Inquirer 25(3): 17-19.

Ginsberg, Allen. 1978. Howl and other poems. N.p.: City Lights. Originally published in 1955. Green, Jonathon. 1999. All Dressed Up: The Sixties and the Counterculture. London: Pimlico. Originally published in 1998.

Grof, Stanislav. 1979. Realms of the Human Unconscious: Observations from LSD Research. London: Souvenir Press. Originally published in 1975.

Heale, M. J. 2001. The Sixties in America. Edinburgh: Edinburgh University Press.

Isserman, Maurice, and Michael Kazin. 2000. America Divided: The Civil War of the 1960s. New York: Oxford University Press.

James, Jenny. 1980. They Call Us The Screamers! Firle, Sussex: Caliban.

Janov, Arthur. 1970. The Primal Scream. New York: Dell Publishing.

---. 1974. The Primal Revolution. London: Garnstone Press. Originally published in 1972.

---. 1978. The Anatomy of Mental Illness. London: Abacus. Originally published in 1971.

---. 1980. Prisoners of Pain. Garden City, NY: Anchor/Doubleday.

---. 1986. Imprints: The Lifelong Effects of the Birth Experience. New York: Coward-McCann.

Kerouac, Jack. 1994. The Dharma Bums. London: Flamingo. Originally published in 1959.

Kimball, Roger. 2000. The Long March: How the Cultural Revolution of the 1960s Changed America. San Francisco: Encounter Books.

Knecht, Curtis. 1991. Primal Therapy - An Experience with Enchantment. Debunking Primal Therapy. http://www.debunkingprimaltherapy.com/former_therapist_article (accessed 9 August 2008).

Kripal, Jeffrey John. 2007. Esalen: America and the Religion of No Religion. Chicago: University of Chicago Press. 
Lacan, Jacques. 1979. The Four Fundamental Concepts of Psycho-analysis, trans. Alan Sheridan. Harmondsworth: Penguin. Originally published in 1973.

---. 1980. Ecrits, trans. Alan Sheridan. London: Tavistock Publications. Originally published in 1966.

Lachman, Gary. 2001. Turn Off Your Mind: The Mystic Sixties and the Dark Side of the Age of Aquarius. London: Sidgwick \& Jackson.

Laing, R. D. 1967. The Politics of Experience and The Bird of Paradise. Harmondsworth: Penguin.

---. 1990. The Divided Self: An Existential Study in Sanity and Madness. Harmondsworth: Penguin. Originally published in 1960 .

Levine, Peter A., and Ann Frederick. 1997. Waking the Tiger: Healing Trauma. Berkeley: North Atlantic.

Lowen, Alexander. 1967. The Betrayal of the Body. New York: Macmillan.

Marcuse, Herbert. 1969. An Essay on Liberation. London: Allen Lane / The Penguin Press.

Marwick, Arthur. 1996. British Society Since 1945. $3^{\text {rd }}$ ed. Harmondsworth: Penguin.

---. 1998. The Sixties: Cultural Revolution in Britain, France, Italy, and the United States, c.1958-c.1974. Oxford: Oxford University Press.

Marx, Karl, and Frederick Engels. 1985. The Communist Manifesto. Harmondsworth: Penguin. Originally published in 1848 .

McFadden, Cyra. 1978. The Serial: A Year in the Life of Marin County. London: Pan-Picador. Originally serialised 1976-77.

Miles [no surname given]. 1995. My Blue Period. Mojo, Nov. Originally published in 1969.

Miller, Stephen Paul. 1999. The Seventies Now: Culture as Surveillance. Durham: Duke University Press.

Neville, Richard. 1971. Playpower. London: Paladin.

Osho. 1983. The Orange Book: The Meditation Techniques of Bhagwan Shree Rajneesh. Rajneeshpuram, OR: Rajneesh Foundation International.

Perls, Frederick S. 1971. Gestalt Therapy Verbatim. New York: Bantam. Originally published in 1969.

Reich, Wilhelm. 1968. The Function of the Orgasm, trans. Theodore P. Wolfe. London: Panther. Originally published in 1942.

Reps, Paul. 1971. Zen Flesh, Zen Bones. Harmondsworth: Pelican. Originally published in 1957. Rose, Steven. 1998. Lifelines: Biology, Freedom, Determinism. Harmondsworth: Penguin. Originally published in 1997.

Rosen, R. D. 1978. Psychobabble: Fast Talk and Quick Cure in the Era of Feeling. London: Wildwood House.

Salinger, J. D. 1951. The Catcher in the Rye. Boston: Little, Brown and Company. Originally published in 1945-46.

Saunders, James. 1979. Bodies. Ashover, Derbyshire: Amber Lane Press.

Sutherland, Stuart. 1998. Breakdown: A Personal Crisis and a Medical Dilemma. $2^{\text {nd }}$ ed. Oxford: Oxford University Press. 
Suzuki, Daisetz Teitaro. 1959. Zen and Japanese Culture. London: Routledge and Kegan Paul. Originally published in 1938.

Thompson, Hunter S. 1998. Fear and Loathing in Las Vegas. London: Flamingo. Originally published in 1971.

Thoreau, Henry David. 2003. Walden. In The Norton Anthology of American Literature, gen. ed. Nina Baym, $6^{\text {th }}$ ed., vol. B, 1807-1982. New York: Norton. Originally published in 1854.

Tzara, Tristan. 1963. Lampisteries précédées de Sept Manifestes Dada. Paris: J.J. Pauvert. These manifestoes were originally published between 1916 and 1924 .

Van Doren, William. 1980-81. Rev. of Freud, Biologist of the Mind by Frank J. Sulloway. Primal Institute Newsletter, Nov.-Dec. 1980 and Jan. 1981: N.p.

Videgård, Tomas. 1983. The Success and Failure of Primal Therapy. Stockholm: Almqvist \& Wiksell International.

Warburton, Minnie. 1979. Mykonos. New York: Coward, McCann \& Geoghegan.

Weathermen, The. 2003. Bring the War Home. In "Takin' it to the Streets": A Sixties Reader, ed. Alexander Bloom and Wini Breines, $2^{\text {nd }}$ ed., 379-82. New York: Oxford University Press. Originally published in 1970.

Weiss, Neal. 2002. Tears Are Not Enough [Interview with Roland Orzabal]. Yahoo! Music, 22 Jan. http://music.yahoo.com/read/interview/12034981 (accessed 24 May 2008).

Wenner, Jann. 1981. Interview with John Lennon. In The Rolling Stone Interviews: Talking with the Legends of Rock \& Roll 1967-1980, ed. Peter Herbst, 128-155. London: Arthur Barker. Originally published in 1971.

Whitman, Walt. 2003. "Song of Myself." In The Norton Anthology of American Literature, gen. ed. Nina Baym, $6^{\text {th }}$ ed., vol. B, 2146-2189. New York: Norton. Originally published in 1855 in the collection Leaves of Grass.

Wolfe, Tom. 1984. On the Bus. In The Purple Decades, 155-177. London: Penguin. Originally published in 1968.

Youth International Party. 2003. Yippie Manifesto. In “Takin' it to the Streets”: A Sixties Reader, ed. Alexander Bloom and Wini Breines, $2^{\text {nd }}$ ed., 278-79. New York: Oxford University Press. Original date of publication not provided.

Television

"Born Again." Law and Order. First televised 6 Mar. 2002. NBC.

"Hurricane Neddy." The Simpsons. First televised 29 Dec. 1996. Fox.

“I am Furious Yellow." The Simpsons. First televised 4 Apr. 2002. Fox.

"Overload." Crime Scene Investigation. First televised 11 Oct. 2001. CBS.

Film

Easy Rider. Dir. Dennis Hopper. Columbia Pictures, 1969.

Rebel without a Cause. Dir. Nicholas Ray. Warner Brothers, 1955.

Woodstock. Dir. Michael Wadleigh. Warner Bros. Pictures, 1970.

Discography

Dylan, Bob. 1963. "Blowin' in the Wind." Perf. Bob Dylan. The Freewheelin' Bob Dylan. Columbia. 
La Bostrie, Dorothy, Richard Penniman, and Joe Lubin. 1955. "Tutti Frutti." Perf. Little Richard. Single. Specialty.

Lennon, John, and Paul McCartney. 1967. "All You Need is Love." Perf. The Beatles. Single. Apple.

---. 1969. "Come Together." Perf. The Beatles. Abbey Road. Apple.

Lennon, John. 1969. "Cold Turkey." Perf. The Plastic Ono Band. Single. Apple.

---. 1970a. "God." Perf. John Lennon and the Plastic Ono Band. John Lennon / Plastic Ono Band. Apple.

---. 1970b. "I Found Out." Perf. John Lennon and the Plastic Ono Band. John Lennon / Plastic Ono Band. Apple.

---. 1970c. "Look at Me." Perf. John Lennon and the Plastic Ono Band. John Lennon / Plastic Ono Band. Apple.

---. 1970d. "Remember." Perf. John Lennon and the Plastic Ono Band. John Lennon / Plastic Ono Band. Apple.

---. 1970e. "Working-Class Hero." Perf. John Lennon and the Plastic Ono Band. John Lennon / Plastic Ono Band. Apple.

Orzabal, Roland. 1982a. "Ideas as Opiates." Perf. Tears for Fears. B-side. Mercury.

---. 1982b. "Mad World." Perf. Tears for Fears. Single. Mercury.

---. 1983. "The Prisoner." Perf. Tears for Fears. The Hurting. Mercury.

\section{NOTES}

i. This article is not a history of Primal Therapy. Nor does it attempt to measure its efficacy, nor try to draw together or disavow the connections between Primal Therapy and (arguably) related successor therapies. Those matters are beyond the scope of the research questions under investigation here and are already the subject of scrutiny and intricate debate. As an example of this, see a small portion of the dialogue surrounding the veracity of Primal Therapy's Wikipedia entry: http://en.wikipedia.org/wiki/ User_talk:GrahameKing/Archive_2

ii. For example, the phrase has been used by a Scottish rock band (Primal Scream, founded 1982), political commentators (Anon. 2005), academics (Field and Stewart 2007) and comic creators (Furman, Delbo and Senior 2002).

iii. Paul Blake, a critic of the 1980s de-politicisation of Primal Therapy (1985), recalls a patient singing a song about Primal Therapy at an Institute group session. The explicit meaning of the title "Up Against the Wall" was that neurotic symptoms could only be resolved by lying next to the Institute's walls and 'having a feeling', but, if this recollection is accurate, then consciously or unconsciously the songwriter was also recycling a slogan advocating countercultural violence: 'Up against the wall, motherfucker!' (informal interview with Paul Blake, Exeter, UK, July 2007) iv. It is unlikely this is accidental. In the mid 1980s Janov submitted an article on the dialectics of healing to a journal - Damocles - focused on the interface between psychology and politics. The article (still unpublished to our knowledge) drew explicitly on Engels's "The Dialectics of Nature" (1975) in constructing its own theory (correspondence with Damocles editorial board, August 2008). 
v. Primal Therapy diminished in the popular imagination in the late 1970s, but its ideas were given currency in British popular music in the early 1980s by the group Tears for Fears. The group's name and the titles of their work provide a quick reference point for their documented interest in Janov's ideas (Weiss 2002): "Ideas as Opiates", "Mad World", and 1983 album The Hurting.

vi. Tomas Videgård's The Success and Failure of Primal Therapy (1983) is nuanced in its conclusions but small in scale and methodologically dubious.

\section{AUTEURS}

PAUL WILLIAMS

Dr. Paul Williams, University of Plymouth (UK)

BRIAN EDGAR

Professor Brian Edgar, Yunnan University (PRC) 